\title{
How is The Development of Valid and Practical Android- Based Local Wisdom Teaching Materials?
}

\section{M Mudiartana ${ }^{\text {* }}$, I G Margunayasa ${ }^{2}$, D G H Divayana ${ }^{3}$}

1,2 Program Studi Pendidikan Dasar, Universitas Pendidikan Ganesha

${ }^{3}$ Program Studi Pendidikan Teknik Informatika, Universitas Pendidikan Ganesha

\section{A R T I CLE I N F O}

Article history:

Received June 12, 2021

Revised June 15, 2021

Accepted August 04, 2021

Available online August 25, 2021

Kata Kunci:

Bahan Ajar Digital, Kearifan Lokal, Validitas, Kepraktisan

Keywords:

PBL, Mathematics Problem Solving Ability

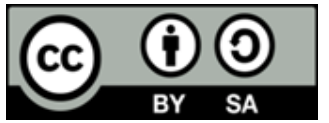

This is an open access article under the CC BY-SA license.

Copyright $(2021$ by Author. Published by Universitas Pendidikan Ganesha.

\begin{abstract}
A B S T RAK
Pandemi Covid-19 menyebabkan proses pembelajaran beralih dari tatap muka menjadi tatap maya. Penelitian ini bertujuan untuk menghasilkan produk berupa bahan ajar digital berkearifan lokal berbasis android untuk kelas $V$ sekolah dasar yang valid dan praktis. Penelitian ini merupakan penelitian pengembangan (Research and Development) dengan model ADDIE (Analysis, Design, Development, Implementation, Evaluation). Subjek penelitian ini adalah bahan ajar digital berkearifan lokal berbasis android, sedangkan objek penelitian adalah validitas dan kepraktisan bahan ajar digital berkearifan lokal berbasis android. Data dalam penelitian ini diklasifikasikan menjadi dua yakni data kualitatif dan data kuantitatif. Teknik pengumpulan data menggunakan teknik kuesioner. Kuesioner digunakan untuk mengukur validitas dan kepraktisan bahan ajar digital. Validitas diuji oleh masing-masing 2 orang ahli yakni ahli materi dan ahli media. Kepraktisan bahan ajar digital dinilai oleh 5 orang guru dan 10 orang siswa kelas V SD di Gugus Letda Kajeng. Data yang terkumpul kemudian dianalisis secara deskriptif kuantitatif. Hasil dari penelitian ini menunjukkan bahwa, (1) validitas bahan ajar digital berkearifan lokal berbasis android diperoleh rata-rata sebesar 3,64 atau berada pada interval 3,50 $\leq R v \leq 4,00$ dengan kriteria "sangat valid"; (2) kepraktisan bahan ajar digital berkearifan lokal berbasis android berdasarkan penilaian guru dan siswa diperoleh rata-rata 3,67 yang berada pada interval 3,50 $\leq R k \leq 4,00$ dengan kategori "sangat praktis". Berdasarkan hasil penelitian disimpulkan bahwa penelitian pengembangan ini menghasilkan bahan ajar digital berkearifan lokal berbasis android pada topik panas dan perpindahannya untuk kelas $V$ sekolah dasar yang sangat valid dan sangat praktis.
\end{abstract}

\section{A B S T R A C T}

The Covid-19 pandemic has caused the learning process to shift from face-to-face to virtual. This research aimed to produce android-based local wisdom digital teaching materials for grade $\mathrm{V}$ of valid and practical elementary schools. This research was a research development (R\&D) with ADDIE model (Analysis, Design, Development, Implementation, Evaluation). The subject of this research was android-based digital teaching materials with local wisdom. In contrast, the research object was the validity and practicality of android-based digital teaching materials with local wisdom. The data in this study were classified into two qualitative and quantitative data. Data collection techniques were using questionnaire techniques. The questionnaires are used to measure the validity and practicality of digital teaching materials. The validity was tested by two experts, namely material experts and media experts. The practicality of digital teaching materials was assessed by five teachers and ten grade $\mathrm{V}$ elementary school students in the Letda Kajeng Cluster. The data collected was then analyzed descriptively quantitatively. The results of this study indicate that (1) the validity of android-based digital teaching materials with local wisdom obtained an average of 3,64 or is in the interval of 3,50 $\leq$ Rv $\leq 4,00$ with the criteria "very valid"; (2) the practicality of digital teaching materials with local wisdom based on the teacher's and student assessment obtained an average of 3,67 which is in the interval of $3,50 \leq R k \leq 4,00$ with the category "very practical". Based on the study results, it was concluded that this development research produced Android-based digital teaching materials with local wisdom on Panas dan Perpindahannya topics for grade $V$ elementary school, which were very valid and very practical. 


\section{INTRODUCTION}

The covid pandemic is currently sweeping all parts of the world, with many changes experienced by all fields. Likewise, in the field of learning, education that should be done face-to-face must turn into online learning, and all activities such as seminars, workshops, conferences, and other activities are postponed and even canceled (Mishra et al., 2020; Oyedotun, 2020; Patricia, 2020; Sahu, 2020). Online learning does not have to demand that learners and educators are in the same room, able to activate students in the learning process, and of course, this learning is more flexible (Friedman \& Friedman, 2013; Nugroho et al., 2021; Sriyanti et al., 2021). This learning can at least prevent the spread of Covid-19. Online learning allows students to exchange opinions with others and provides opportunities for learners to learn independently (Hwang et al., 2020; Wei et al., 2021). Online learning allows learners to share their opinions and learn more independently without any time limits and in more flexible spaces (Hwang et al., 2020; Kkese, 2020; Lage-Cala et al., 2020). Online learning requires the ability of educators and learners because the ability to use technology will greatly help create a more conducive learning atmosphere so that good social interaction is formed (Andel et al., 2020; Chang \& Lan, 2019). In addition to the ability of online learning must also pay attention to the financial condition of learners and the facilities and infrastructure that support online learning (Anitha Kumari et al., 2020; Rusli et al., 2020). Educators must think about how to create a learning atmosphere that agrees with the current conditions, the characteristics of learners, and, of course, realize the goals of National Education and produce people who are ready to compete in the global world. Success in learning has four main components: goals, materials, methods, and assessment tools (Andani \& Yulian, 2018; Diartini \& Ratnawuri, 2017). One of the most important components is teaching materials.

Teaching materials will positively impact learning (Silalahi, 2020; Sriyanti et al., 2021; Yilmaz \& Korur, 2021). Currently, the teaching materials that should be developed are teaching materials that can be used in the online learning process, which is different from the existing modules in the form of hardcopy. Teaching materials become one of the important factors in learning (Handayani et al., 2021; Hidayah \& Priscylio, 2019). Teaching materials allow teachers to convey the material well to learners (Hamid et al., 2021; Martha \& Andini, 2019). Teaching materials are one part of the learning process, so learning design must be arranged systematically (Pasaribu \& Saparini, 2017; Shafii, 2017). Teaching materials are arranged to provide materials for learning that follow the curriculum's demands (Pratiwi et al., 2017; Rasmawan, 2018). Teaching materials are knowledge, skills, and attitudes that must be learned to achieve predetermined competency standards. Teaching materials can attract students because they have attractive designs and images (Asriani et al., 2017; Gustiawati et al., 2020). The importance of teaching materials in the learning process, demanding that teachers can develop teaching materials that are in line with the needs of learners, curriculum demands, not dependent on textbooks and government assistance package books, as well as in line with the character of learners (Andani \& Yulian, 2018 ; M. Cloonan \& Fingeret, 2020; Weriyanti et al., 2020). Development of teaching materials following the demands of the curriculum and the needs of students, namely teaching materials under the characteristics and environment of students (Mayarnimar \& Taufina, 2017; Weriyanti et al.). With the appropriate teaching materials with the curriculum, needs and characteristics will increase student motivation and learners can learn according to science and technology development (Suzuki et al., 2020; Tchen et al., 2018). In addition, teaching materials can increase learners' creativity (Hamzah \& Mentari, 2017; Tsai et al., 2017). So, the presence of quality teaching materials will have an impact on the motivation, interest, creativity that results in the learning outcomes of learners.

However, based on the study results of the student book document theme 6 grade $\mathrm{V}$ elementary school on the NATURAL SCIENCE load, in particular, the hot topic and displacement obtained that the material available in the book is very limited. Online questionnaire data support this statement addressed to teachers and students of class V of the 2020/2021 school year at SD Group Letda Kajeng North Denpasar District on January 25-30, 2021. The questionnaire results showed that: (1) of the 9 V-class teachers, $56 \%$ of them stated that the NATURAL SCIENCE content material listed in the student handbook is still shallow. The explanation is still very few sentences. In addition, some explanations of the material in the book have not been equipped with images. (2) $78 \%$ of teachers stated that the teacher needs to develop the NATURAL SCIENCE content material in the student book because the teacher only uses textbooks for as long as possible. Learning, and (3) 75\% of students state that NATURAL SCIENCE content material, especially on the topic of Heat and Displacement contained in student books, needs to be developed in android-based local wisdom digital teaching materials. Distance Learning observations conducted on teachers in SD Negeri 12 Disarming found that most teachers only use teaching materials in printed books or handouts, which are then photographed and sent through WhatsApp groups. While when viewed from the student side, most students today have become accustomed to using android mobile devices. Currently, existing teaching materials have not been able to develop the courage and skills of 
students in asking questions and opinions (Sriyanti et al., 2021; Weriyanti et al., 2020) Currently, the learning process only uses a student's book, which needs to be supervised and added material that is in line with the needs of students. Teachers mostly use teaching materials from package books that are also combined with general history reading books. If this condition greatly affects learners' ability to understand the defended material, this certainly impacts learning outcomes. One solution that can be offered is to develop digital teaching materials based on local wisdom.

Digital teaching materials are teaching materials that integrate information technology and computing (Handayani et al., 2021; Silalahi, 2020). At the same time, android-based digital teaching materials are digital teaching materials developed using android applications. This teaching material is presented using android-based applications (Hamid et al., 2021; Sriyanti et al., 2021). Students can only install this application on their android device to access learning materials independently in this pandemic period. Digital teaching materials made by teachers must also pay attention to the content in the teaching material. The content of the teaching material closest to the student has a close relationship with the community environment (local wisdom) in which the student is located. Local wisdom related to indigenous knowledge and culture in certain communities is always developed over time and experiencing development (Komara et al., 2020; Yunita \& Tristiantari, 2018). Similarly, with teaching materials, android-based digital teaching materials developed by adapting local wisdom can form good social solidarity, the foundation of a sense of unity (Joyo, 2018; Khoeriyah \& Mawardi, 2018).

Teaching materials developed using a local wisdom approach can provide students with a more meaningful learning experience. Local wisdom integrated into android-based digital teaching materials is tailored to the topics/materials discussed. One of the local wisdom activities in Bali related to the NATURAL SCIENCE lesson load is heat, and displacement is burning satay. Satay burning activities are routinely carried out in Bali's traditional activities, such as religious ceremonies, pawiwahan (wedding), and ngaben. The burning satay activity can appear as material content related to heat and displacement, namely conduction, convection, and radiation. The development of thematic teaching materials based on local wisdom was developed to overcome the difficulties experienced in schools. The availability of teaching materials by local environmental conditions is inadequate (Alba et al., 2019; Feces et al., 2017). Integrating culture into the learning process will have a positive outlook for students and cultural sustainability. Teaching materials based on local wisdom to preserve cultural values (Hest et al., 2021). Local content-based teaching materials can improve learning outcomes. This is because teaching materials are more interesting and make learners learn more actively (Faisal \& Sulkipani, 2016).

The findings of previous research stated that digital teaching materials could facilitate students in learning independently (Astalini et al., 2019; Handayani et al., 2021; Majid et al., 2012). Other research findings also state that digital teaching materials can make it easier for students to understand the subject matter (Boyd, 2019; Irwansyah et al., 2017; Linda et al., 2018). Some research on teaching materials that have been developed states that local content-based teaching materials / local wisdom can make practice natural sciences more enthusiastic in the following learning both at the elementary and college levels (Hutama, 2016; Kormasela et al., 2020; Nurafni et al., 2020; Princess et al., 2018). The development of local wisdom-based teaching materials can improve learners' writing skills (Owon, 2017), hone learners' language skills (Saidah \& Damariswara, 2019), motivated them to learn more actively (Lestariningsih \&Suardiman, 2017). So, it can be said that the development of local wisdom-based teaching materials will positively impact the learning process. Some of these studies integrate some cultures in the learning process, especially Maluku culture, west Java, East Java, and many more. This research aims to produce Android-based, locally based digital teaching materials for good and practical elementary school V classes. It is hoped that locally discerning digital teaching materials can facilitate students' learning so that the impact on student learning outcomes increases.

\section{METHOD}

This research included the type of development research or Research and Development (R\&D). Research and Development is a research method used to measure the validity, practicality, and effectiveness of a product being developed. In education, research and development or Research and Development is a research method used to develop or validate products used in education and learning. One model that is widely used in development research is the ADDIE model. The ADDIE model was first developed by Robert Maribe Branch (Sugiyono, 2018). ADDIE stands for Analysis, Design, Development, Implementation, Evaluation. An analysis is concerned with work analysis and the environment to find what products need to be developed. Design a product design activity following what is needed. Development is the manufacturing and testing of products. Implementation is the activity of using products. Evaluation is the activity of assessing whether every step of the activity and product made is by the specifications or not. 
The data collected in this study used questionnaire techniques. A questionnaire is a data collection technique that gives respondents a set of questions or written statements to answer (Sugiyono, 2018). Questionnaires are given as preliminary studies to find problems in the learning process as things to be studied. The questionnaire was given by sending questions online through google form to respondents: teachers and students of class V of The State Elementary School Letda Kajeng, Denpasar, Bali. The questionnaire results will be used as preliminary data to develop locally-based digital teaching materials based on android. The questionnaires used in the study were closed-type questionnaires. That was, respondents only give answers to questions that have available answers. The study used two types of questionnaires: validation questionnaires and practicality questionnaires. Validation questionnaires were given to media experts and material experts. In contrast, the product practicality questionnaire was given to teachers in class $\mathrm{V}$ of Letda Kajeng Group and class V students in the same group. The questionnaire grid used in the study, seen in the following table.

Table 1. Content Expert Questionaire Grid

\begin{tabular}{lll}
\hline Variable & Indicator & Instrument Item Number \\
\hline Content eligibility & Material conformity with Basic & $1,2,3$ \\
& Competency & \\
& Accuracy of material & $4,5,6,7,8$ \\
& Material update & 9,10 \\
& Encourage curiosity & 11,12 \\
Presentation eligibility & Presentation techniques & 1 \\
& Presentation support & $2,3,4,5,6,7$ \\
& Presentation of learning & 8 \\
& Coherence and traces of the flow of & 9,10 \\
& thought & $1,2,3$ \\
& Fluence & 4 \\
& Communicative & 5 \\
& Dialogical and interactive & 6,7 \\
& Conformity with the development of & \\
& learners & 8,9 \\
\hline
\end{tabular}

Table 2. Media Expert Questionnaire Grid

\begin{tabular}{lll}
\hline Variable & Indicator & Instrument Item Number \\
\hline Graphics eligibility & Artistic and Aesthetic & $1,2,3,4,5$ \\
& Ease of navigation & $6,7,8,9$ \\
& Overall function & $10,11,12$ \\
\hline
\end{tabular}

Table 3. Practicality Questionnaire Grid for Teachers

\begin{tabular}{lll}
\hline Variable & Aspect & Instrument Item Number \\
\hline Wisdom and usefulness & Product management & $1,2,3,4$ \\
& Ease of use of the product & $5,6,7,8,9,10,11,12$ \\
& Product benefits & $13,14,15,16,17,18$ \\
\hline
\end{tabular}

Tabel 4. Practicality Questionnaire Grid for Students

\begin{tabular}{lll}
\hline Variable & Aspects & Instrument Item Number \\
\hline Wisdom and & Product management & $1,2,3,4$ \\
usefulness & Ease of use of the product & $5,6,7,8,9,10,11,12,13$ \\
& Product benefits & $14,15,16,17,18$ \\
\hline
\end{tabular}

Before being used to measure the validity and practicality of the product, the instrument is first validated by experts (expert judges). The data obtained was analyzed using analysis techniques incorporated into Gregory's table, which is cross tabulation divided into four parts, namely A, B, C, and D. The validity value of the content obtained reflects the entire resulting test item. To classify the results of the validity of the contents obtained, it can be determined based on Table 2 below. 
Table 6. Content Validity Category

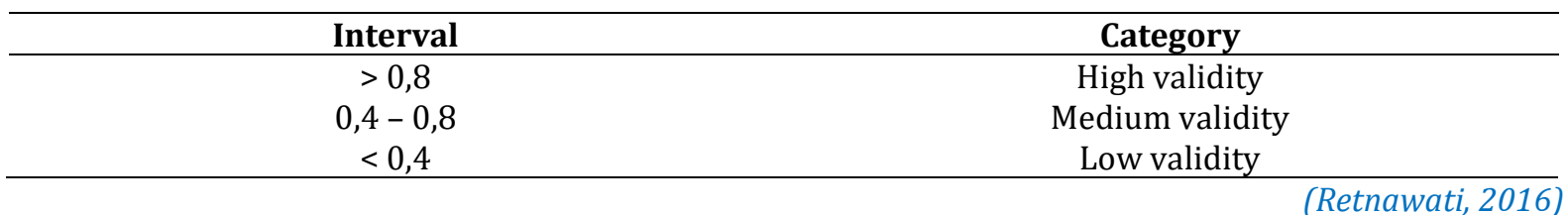

Based on the results of cross-tabulation of judges' assessment, the instruments used to test the validity of products from both material experts and media experts in this study were at intervals of $>0.8$. This suggests that the questionnaire had very high validity and was worth using to test digital teaching materials. Similarly, the cross-tabulation results of judges' assessments showed that the instruments used to test the practicality of products by teachers and students were at intervals of $>0.8$ or had high validity. This suggests that the questionnaire was worth using to test the practicality of android-based digital teaching materials. Furthermore, a valid instrument was used to measure the validity and practicality of the digital teaching materials developed. The teaching material was said to be valid if the results of data analysis were at intervals of $2.50 \leq \mathrm{Rv} \leq 4.00$. Furthermore, tests were conducted on teachers and students to obtain user response data of digital teaching materials that have been valid. Respondents to this trial were five teachers of class $\mathrm{V}$ elementary school and ten students of class $\mathrm{V}$ elementary school in Cluster Letja Kajeng. The resulting android-based digital teaching material was practical if the data analysis results were at intervals of $2.50 \leq \mathrm{Rk} \leq 4.00$.

\section{RESULT AND DISCUSSION}

\section{Result}

To support the optimization of online learning during pandemic, android-based digital teaching materials were needed. The learning was done virtually and remotely, so teaching materials also need to be published digitally. Therefore, it was necessary to develop android-based digital teaching materials. Android-based teaching materials are feasible and can be implemented in learning, especially during the covid-19 pandemic. The validation process of android-based digital teaching materials was carried out based on pre-made assessment instruments and serves to measure the validity of digital teaching materials before field tests were conducted. The validation process of android-based digital teaching materials used two validators, namely material experts and media experts. Based on the calculation results in Table 7 , the overall average validity test result is 3.64 . At intervals of $3.50 \leq \mathrm{Rv} \leq 4.00$, it indicated that digital teaching materials were included in the criteria are very valid. This proves that android-based digital teaching materials in content, including materials and media, were worth using later, namely the test of product practicality in teachers and students. Digital teaching materials validated by experts and improved following the input of experts are then piloted to 5 teachers and ten students of class $\mathrm{V}$ of The Letda Kajeng State Elementary School. Teachers and students assess the practicality of teaching materials, including aspects of spirituality, ease of use, and the benefits of digital teaching materials.

Based on the results of the data analysis, the average teacher and student assessment of the practicality of android-based digital teaching materials amounted to3.67and was at intervals of $3.50 \leq \mathrm{Rk} \leq 4.00$. This shows that android-based, locally based digital teaching materials fall into the category of very practical. This research aims to produce android-based locally-based digital teaching materials that are tested for validity and practicality. To obtain valid and practical teaching materials in this development, use five stages in the ADDIE model. These stages are Analysis, Design, Development, Implementation, and Evaluation. However, due to time constraints and the situation of the covid-19 pandemic, the stage only reaches the development stage. Activities in this stage can be explained as follows:. First, the analysis stage. At this stage, two activities were carried out, namely analysis of the curriculum and analysis of the needs of teachers and students. Curriculum analysis was conducted to obtain a mapping of Core Competencies (KI), Basic Competencies (KD), and Competency Achievement Indicators (GPA). Researchers conducted material design, student worksheets, and quizzes on digital teaching materials developed based on this mapping. Meanwhile, the needs analysis was carried out to determine the needs of students and teachers in the Letda Kajeng Cluster of North Denpasar Subdistrict, Denpasar City. This analyst on the needs of teachers and students was done by providing online questionnaires to teachers and grade $\mathrm{V}$ elementary school students. Based on the analysis of the needs of teachers and students, it was obtained that the development of android-based digital teaching materials on hot topics and displacement is necessary. 
The second, the design stage. At this stage, two activities are carried out, namely the design of teaching materials and instruments used to test the validity and practicality of teaching materials. Android-based digital teaching materials design began with selecting developer applications, designing interfaces, and designing content. There was also this stage of instrument design and validation of instruments that have been made suitable for use to test the validity and practicality of teaching materials. The third, the development stage. Two activities were carried out at this stage: developing digital teaching materials products and assessment activities on products developed. The product development stage included building new applications in androjex, creating application pages, and filling in material content in text, videos, images, problem examples, LKPD, and quizzes. At this stage, product assessment was also carried out by experts to find out the level of validity and practicality of the product.

This research has produced android-based and locally-based digital teaching materials on hot topics and displacement. This digital teaching material was an android-based application with an apk extension installed on all Android versions. Characteristics of this android-based digital teaching material are: (1) This android-based digital teaching material can work on all versions of the android operating system (OS) with an extension apk; (2) In this application contains 6 main pages, namely, startuppage, home page, info page, study page,teacher's page, and my account page; (3) On the startup page there is an illustration that fully illustrates the display of teaching materials on hot topics andtheir displacement for grade Velementary school; (4) On the home page contains a picture with a welcome message and the name of the applicationand congratulations on learning; (5) On the info page there are 6 subpages, namely introduction, material topics, glossaries, reference lists, usage and about applications; (6) On the study page there are 4 subpages namely temperature and heat, temperature gauge, panastransfer, and conductors and insulators; (7) On the teacher's page there is information about the name, address, email, and contact number of the teacher that can be contacted directly by the student; (8) On my account page there is information about the creation of an account by students as a form of registration already using and installing teaching material applications on hot topics and displacement; (9) The background image on each page uses interesting animated images and hookswith local Balinesewisdom; (10) Icons used in the application use animations that are interesting and in accordance with the content in them. The interface display of digital teaching materials that are the result of this study, as seen in figure 1 . Following the purpose of the research, android-based local wisdom digital teaching materials that were developing products in this research must be tested for validity and practicality by experts/practitioners, teachers, and students. The validity of digital teaching materials was measured using instruments that expert judges have validated. The validity of digital teaching materials was measured from aspects of content feasibility, presentation feasibility, language feasibility, and radiography feasibility (BSNP in Anud, 2019). 2 material experts from lecturers assessed the feasibility of content, presentation feasibility, and language feasibility. While the feasibility of photography was assessed by two media experts who also come from lecturers.

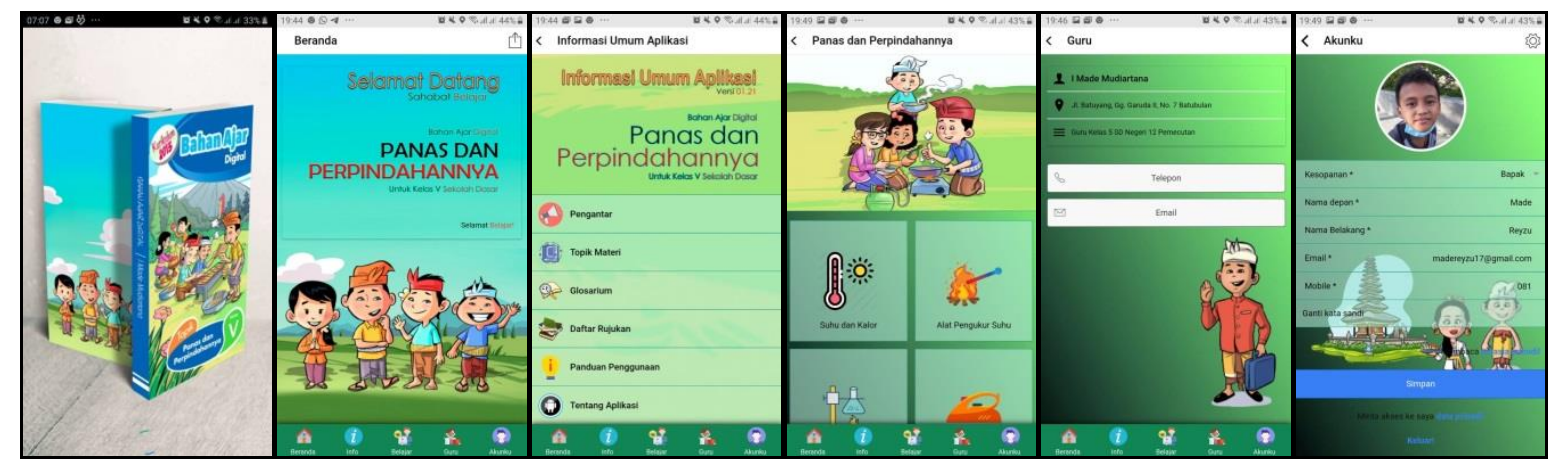

Figure 1. Results of Digital Teaching Materials Development

Based on the assessment of 2 experts, the material obtained the results of the feasibility of content, presentation feasibility, and language eligibility got a score of 3.85. It was at an interval of $3.50 \leq$ $\mathrm{Rv} \leq 4.00$, which indicates that android-based digital teaching materials are included in the criteria are very valid. Meanwhile, based on the teaching material validity test results, two media experts obtained a score of 3.42. They were at an interval of $2.50 \leq \mathrm{Rv} \leq 3.50$, which showed that digital teaching materials were included in the valid criteria. Meanwhile, the results of a practicality assessment by five teachers of android-based locally based digital teaching materials have obtained a score of 3.78. They were at intervals of $3.50 \leq \mathrm{Rk} \leq 4.00$, which showed that android-based digital teaching materials were very 
practical. In comparison, the results of practicality assessment by ten students against the practicality of android-based digital teaching materials amounted to 3.55 and were at intervals of $3.50 \leq \mathrm{Rk} \leq 4.00$. This showed that this android-based digital teaching material falls into the category of very practical..

\section{Discussion}

The results stated that thematic teaching materials based on local wisdom in the " Beautiful Cultural Diversity of My Country " for grade IV elementary school students were declared fit for use. Like this teaching, the material was inseparable from the development steps carried out. The analysis stage provided an overview of how teaching materials were needed in the learning process. The results of the analysis of the desired teaching material were teaching material consisting of interesting images and following the material. Teaching materials with interesting images will make students more motivated and interested in reading (Afifah et al., 2016; M. R. Cloonan et al., 2020). In addition, the results of the needs analysis also obtained that what was needed by students today is teaching materials that make it easier for students to understand the material that is being defended and teaching materials that students in their daily lives find. The importance of teaching materials in the learning process requires teachers to be able to develop teaching materials that are in line with the needs of learners, curriculum demands, not dependent on textbooks and government assistance package books, and in line with the characteristics of learners (Andani \& Yulian, 2018; M. Cloonan \& Fingeret, 2020; Mayarnimar \& Taufina, 2017; Weriyanti et al., 2020). Appropriate teaching materials, curriculum, needs, and characteristics will increase student motivation, and learners can learn according to science and technology development (Irwansyah et al., 2017; Suzuki et al., 2020) In addition, teaching materials can increase the creativity of learners (Triwahyuningtyas et al., 2020; Tsai et al., 2017). So, the presence of quality teaching materials will impact the activity, interest, creativity that results in the learning outcomes of learners..

Developing material through teaching materials becomes the most relevant solution when considering the diversity of competence, creativity, and teaching patterns of teachers in various schools (Prihandoko et al., 2017; Velan et al., 2015). The development of thematic teaching materials based on local wisdom was developed to overcome the difficulties experienced in schools. The availability of teaching materials following local environmental conditions is not adequate (Alba et al., 2019; Feces et al., 2017). Integrating culture in the learning process will positively impact students and cultural sustainability - teaching materials based on local wisdom to preserve cultural values (Hest et al., 2021). Local content-based teaching materials can improve learning outcomes, and this is because teaching materials are more interesting and make learners learn more actively (Faisal \& Sulknatural science, 2016; Yulando et al., 2019). So, it can be said that the development of teaching materials based on local wisdom will positively impact the learning process. Some cultures are integrated in the learning process, especially Maluku, West Java, East Java, and many more.

The design stage. The teaching book whose design was concerned with existing materials and integrated with local Balinese culture. This design was certainly inseparable from the character of learners by paying attention to students in designing a teaching material would help students more easily in understanding the material. In addition, the selection of colors, letters, and characters in a teaching material will affect the student's understanding. Color, font size, the typeface should be made more attractive (Riwu et al., 2018), which will make the shepherded teaching material more suitable for use. Development of teaching materials that follow the demands of the curriculum with the needs of students, namely teaching materials that are by the characteristics and environment of students(Mayarnimar \& Taufina, 2017; Weriyanti et al., 2020). Images on teaching materials similar to the material can attract students' attention in the learning process (Firdaus \& Mukhaiyar, 2021). Image media presentations can motivate students (Dewi et al., 2018; Nurjannah, 2018). Color, the size of the typeface of teaching materials developed determines the feasibility of teaching material.

At this stage, local wisdom-based teaching materials are declared valid in material, language, and design. Teaching materials are valid if they meet the material requirements, have easy-to-understand language, and design according to the student's character and interest (Irman \& Waskito, 2020; Lestar, 2021). Teaching materials with good content, easy-to-understand language, and interesting designs can help students understand the material (Estuwardani \& Mustadi, 2016), adding insight and encouraging students to learn more actively and independently (Yati \& Amini, 2020). The results of this study strengthen the research that states that the teaching materials that have been developed state that local content-based teaching materials / local wisdom can make the practice of natural sciences more 
enthusiastic in the following learning both at the elementary and college levels (Hutama, 2016; Kormasela et al., 2020; Nurafni et al., 2020; Princess et al., 2018). The development of local wisdom-based teaching materials can improve learners' writing skills (Owon, 2017), hone learners' language skills (Saidah \& Damariswara, 2019), motivated to learn more actively (Lestariningsih \&Suardiman, 2017). Thematic teaching materials based on local wisdom in elementary schools that have an impact on learning outcomes (Tinja et al., 2017), thematic teaching materials on poetry subjects (Wibowo et al., 2017), on the theme of "ayok cinta Lingkungan" in elementary school (Indrawini et al., 2017). Tournament-type suitable teaching materials are applied in decent, practical, and effective elementary schools (Yati \&Amini, 2020). Developing thematic-integrative teaching materials based on local wisdom improves caring character and responsibility (Lestariningsih \&Suardiman, 2017). Development of Integrative Thematic Learning Modules Subtheme of Living Things Relations in the Ecosystem scientific approach (Arum \& Wahyudi, 2016). So, the teaching materials developed were worth using and effective to improve learning outcomes and motivate students to learn..

The findings of previous research stated that digital teaching materials packed with interest would facilitate students in understanding learning materials (Liu et al., 2021; Neppala et al., 2018). Other research findings also state that digital teaching can improve student learning outcomes (Astalini et al., 2019; Lee \& Osman, 2012; McNamara et al., 2020). Other research also states that digital teaching materials can increase student motivation in learning (Handayani et al., 2021; Irwansyah et al., 2017). It can be concluded that digital teaching materials can help students in learning. The disadvantage of this study is the non-implementation of the implementation stage to test the effectiveness of android-based digital teaching materials. The non-implementation of this stage was due to time constraints and the situation of the covid-19 pandemic so that it cannot bring students to school en masse. This research has produced a product in the form of a locally-based digital teaching material application based on android on the topic of Heat and Displacement that tested its validity and practicality. Although this digital teaching material has not been mass-piloted, the results of this study have implications such as: (1) Theoretically, the product of this research can add to the characteristics of science in the field of education, especially the topic of Heat and Displacement of grade V elementary school; (2) This androidbased digital teaching material can be used as an alternative for teachers and students of grade $\mathrm{V}$ elementary school in distance learning activities in pandemic times because the use of this teaching material is not limited to space and time; (3) The integration of local wisdom in this digital teaching material includes characterizing material, and examples that exist around students. The integration of local wisdom then learning with this teaching material can be useful and meaningful; (4) The results of this study can be used as a reference for other researchers who want to develop similar products.

\section{CONCLUSION}

Based on the results of data analysis, the development of android-based digital teaching materials gets an excellent category from experts. It can be concluded that android-based digital teaching materials are worth applying in the learning process. It was recommended for the teachers to use android-based digital teaching materials to facilitate students in self-learning.

\section{REFERENCES}

Afifah, E., Triyono, T., \& Hotifah, Y. (2016). Pengembangan Media Letter Sharing Untuk Meningkatkan Keterampilan Komunikasi Siswa Introvert. Jurnal Kajian Bimbingan Dan Konseling, 1(2), 27-32. https://doi.org/10.17977/um001v1i12016p027.

Alba, A. P., Akbar, S., \& Nurchasanah, N. (2019). Bahan Ajar Tema Daerah Tempat Tinggalku Berbasis Kearifan Lokal. Jurnal Pendidikan: Teori, Penelitian, Dan Pengembangan, 4(4), 421-426. https://doi.org/10.17977/jptpp.v4i4.12228.

Andani, D. T., \& Yulian, M. (2018). Pengembangan Bahan Ajar Electronic Book Menggunakan Software Kvisoft Flipbook Pada Materi Hukum Dasar Kimia di SMA Negeri 1 Panton Reu Aceh Barat. Jurnal IPA \& Pembelajaran IPA, 2(1), 1-6. https://doi.org/10.24815/jipi.v2i1.10730.

Andel, S. A., de Vreede, T., Spector, P. E., Padmanabhan, B., Singh, V. K., \& Vreede, G. J. de. (2020). Do social features help in video-centric online learning platforms? A social presence perspective. Computers in Human Behavior, 113(April), 106505. https://doi.org/10.1016/j.chb.2020.106505.

Anitha Kumari, T., Hemalatha, C. H., Subhani Ali, M., \& Naresh, R. (2020). Survey on impact and learning's of the online courses on the present era. Procedia Computer Science, 172, 82-91. https://doi.org/10.1016/j.procs.2020.05.167. 
Arum, T. S., \& Wahyudi, W. (2016). Pengembangan Modul Pembelajaran Tematik Integratif Subtema Hubungan Makhluk Hidup Dalam Ekosistem Pendekatan Saintifik Untuk Kelas 5 Sd. Scholaria: $\begin{array}{lllll}\text { Jurnal Pendidikan } & \text { Dan }\end{array}$ https://doi.org/10.24246/j.scholaria.2016.v6.i3.p239-250.

Asriani, P., Sa'dijah, C., \& Akbar, S. (2017). Bahan Ajar Berbasis Pendidikan Karakter Untuk Siswa KElas IV Sekolah Dasar. Jurnal Pendidikan: Teori, Penelitian, Dan Pengembangan, 2(11), 1456-1468. https://doi.org/10.17977/jptpp.v2i11.10160.

Astalini, A., Darmaji, D., Kurniawan, W., Anwar, K., \& Kurniawan, D. A. (2019). Effectivenes of Using EModule and E-Assessment. International Journal of Interactive Mobile Technologies (IJIM), 13(09), 21-39. https://doi.org/10.3991/ijim.v13i09.11016.

Boyd, L. (2019). Using Technology-Enabled Learning Networks to Drive Module Improvements in the UK OpenUniversity. Journal of Interactive Media in Education, 2019(1), 1-7. https://doi.org/10.5334/jime.529.

Chang, M. M., \& Lan, S. W. (2019). Exploring undergraduate EFL students' perceptions and experiences of a Moodle-based reciprocal teaching application. Open Learning: The Journal of Open, Distance and eLearning. https://doi.org/10.1080/02680513.2019.1708298.

Cloonan, M., \& Fingeret, A. L. (2020). Developing teaching materials for learners in surgery. Surgery (United States), 167(4), 689-692. https://doi.org/10.1016/j.surg.2019.05.056.

Cloonan, M. R., Cloonan, D. J., Schlitzkus, L. L., \& Fingeret, A. L. (2020). Learners with Experience in Surgical Scrub Benefit from Additional Education with an Interactive E-Learning Module. Journal of the American College of Surgeons, 4(2). https://doi.org/10.1016/j.jamcollsurg.2020.08.521.

Dewi, A., Dewi, L., \& Setiawati, L. (2018). Efektivitas Penggunaan Media Gambar Karikatur Terhadap Peningkatan Motivasi Belajar Siswa Pada Mata Pelajaran Sejarah. Edutcehnologia, 2(1), 1-12. https://ejournal.upi.edu/index.php/edutechnologia/article/view/19654.

Diartini, R., \& Ratnawuri, T. (2017). Penggunaan Model Cooperative Learning Tipe Probing Prompting Berbantu Media Flash Card Terhadap Hasil Belajarips Terpadu. PROMOSI (Jurnal Pendidikan Ekonomi), 5(1), 57-63. https://doi.org/10.24127/ja.v5i1.846.

Faisal, E. El, \& Sulkipani, S. (2016). Pengembangan bahan ajar berbasis muatan lokal pada mata kuliah Pendidikan Kewarganegaraan. Jurnal Civics: Media Kajian Kewarganegaraan, 13(2), 113-126. https://doi.org/10.21831/civics.v13i2.12721.

Firdaus, \& Mukhaiyar, R. (2021). Buku Ajar Berbasis Masalah untuk Mata Pelajaran Dasar Listrik dan

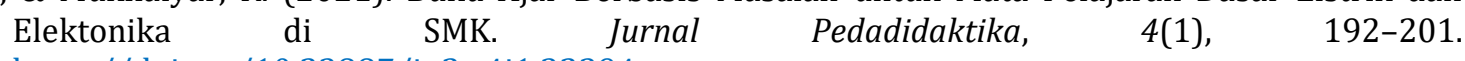
https://doi.org/10.23887/jp2.v4i1.32394.

Friedman, L. W., \& Friedman, H. H. (2013). Using social media technologies to enhance online learning. Journal of Educators Online, 10(1). https://doi.org/10.9743/JE0.2013.1.5.

Gustiawati, R., Arief, D., \& Zikri, A. (2020). Pengembangan Bahan Ajar Membaca Permulaan dengan Menggunakan Cerita Fabel pada Siswa Sekolah Dasar. Jurnal Basicedu, 4(2), 355-360. https://doi.org/10.31004/basicedu.v4i2.339.

Hamid, S. N. M., Lee, T. T., Taha, H., Rahim, N. A., \& Sharif, A. M. (2021). E-Content Module For Chemistry Massive Open Online Course (Mooc): Development And Students' Perceptions. Journal of Technology and Science Education, 11(1), 67-92. https://doi.org/10.3926/jotse.1074.

Hamzah, I., \& Mentari, S. (2017). Development of Accounting E-Module to Support the Scientific Approach of Students Grade X Vocational High School. Journal of Accounting and Business Education, 1(1), 78. https://doi.org/10.26675/jabe.v1i1.9751.

Handayani, D., Elvinawati, E., Isnaeni, I., \& Alperi, M. (2021). Development Of Guided Discovery Based Electronic Module For Chemical Lessons In Redox Reaction Materials. International Journal of Interactive Mobile Technologies (IJIM), 15(07), 94. https://doi.org/10.3991/ijim.v15i07.21559.

Hest, Y. A. L., Riyadi, Kamsiyati, S., \& Purnamasari, V. (2021). Pengembangan Bahan Ajar Berbasis Muatan Lokal Keanekaragaman Motif Batik Ngawi sebagai Sumber Belajar di Kelas V Sekolah Dasar. Jurnal Basicedu, 5(2), 1060-1066. https://doi.org/10.31004/basicedu.v5i1.721.

Hidayah, D. N., \& Priscylio, G. (2019). Pengembangan Bahan Ajar Mandiri Pokok Bahasan Suhu Dan Kalor Menggunakan Software Camtasia. Journal of Teaching and Learning Physics, 4(1), 50-64. https://doi.org/10.15575/jotalp.v4i1.4093.

Hutama, F. S. (2016). Pengembangan Bahan Ajar Ips Berbasis Nilai Budaya Using Untuk Siswa Sekolah Dasar. JPI Uurnal Pendidikan Indonesia), 5(2), 113. https://doi.org/10.23887/jpiundiksha.v5i2.8359.

Hwang, G. J., Wang, S. Y., \& Lai, C. L. (2020). Effects of a social regulation-based online learning framework on students' learning achievements and behaviors in mathematics. Computers and Education, 160, 104031. https://doi.org/10.1016/j.compedu.2020.104031. 
Indrawini, T., Ach. Amirudin, \& Widiati, U. (2017). Pengembangan Bahan Ajar Tematik Subtema Ayok Cintai Lingkungan Untuk siswa SD. Jurnal Pendidikan: Teori, Penelitian, Dan Pengembangan, 2(11), 1489-1497. https://doi.org/10.17977/jptpp.v2i11.10181.

Irman, S., \& Waskito, W. (2020). Validasi Modul Berbasis Project Based Learning pada Mata Pelajaran Simulasi dan Komunikasi Digital. Jurnal Ilmiah Pendidikan Dan Pembelajaran, 4(2), 260-269. https://doi.org/10.23887/jipp.v4i2.26156.

Irwansyah, Lubab, Farida, \& Ramdhani. (2017). Designing Interactive Electronic Module in Chemistry Lessons F S. International Conference on Mathematics and Science Education (ICMScE), 895(1), 17. https://doi.org/10.1088/1742-6596/895/1/012009.

Joyo, A. (2018). Gerakan Literasi Dalam Pembelajaran Bahasa Indonesia Berbasis Kearifan Lokal Menuju Siswa Berkarakter. Jurnal Kajian Bahasa, Sastra Dan Pengajaran (KIBASP), 1(2). https://doi.org/10.31539/kibasp.v1i2.193.

Khoeriyah, N., \& Mawardi, M. (2018). Penerapan Desain Pembelajaran Tematik Integratif Alternatif Berbasis Kearifan Lokal untuk Meningkatkan Hasil dan Kebermaknaan Belajar. Mimbar Sekolah Dasar, 5(2), 63. https://doi.org/10.17509/mimbar-sd.v5i2.11444.

Kkese, E. (2020). McGurk effect and audiovisual speech perception in students with learning disabilities exposed to online teaching during the COVID-19 pandemic. Medical Hypotheses, 144(July), 110233. https://doi.org/10.1016/j.mehy.2020.110233.

Komara, E., Ibrahim, M., \& Adiraharja. (2020). Integrasi Nilai-nilai Kearifan Lokal dalam Pembelajaran Kewirausahaan di SMK Negeri 10 Kota Bandung. Mimbar Pendidikan Jurnal Indonesia, 5(2). https://doi.org/10.17509/mimbardik.v5i2.28870.

Kormasela, D. A., Dawud, D., \& Rofi'uddin, A. H. (2020). Pemanfaatan Kearifan Lokal Maluku dalam Pengembangan Bahan Ajar Menulis Teks Prosedur untuk Siswa Kelas VII. Jurnal Pendidikan: Teori, Penelitian, Dan Pengembangan, 1056-1065. https://doi.org/10.17977/jptpp.v5i8.13872.

Lage-Cala, S., Folgueras-Díaza, M. B., Alonso-Hidalgoa, M., García-Menéndezb, D., \& Fernández-Garcíab, F. J. (2020). Investigation of the effectiveness of online learning tools for energy performance certificates preparation. Energy Reports, 6, 609-614. https://doi.org/10.1016/j.egyr.2019.09.034.

Lee, T. T., \& Osman, K. (2012). Interactive Multimedia Module in the Learning of Electrochemistry: Effects on Students' Understanding and Motivation. Procedia - Social and Behavioral Sciences, 46. https://doi.org/10.1016/j.sbspro.2012.05.295.

Lestar, W. (2021). Pengembangan Modul Pembelajaran Bahasa Inggris Berbasis Andragogi Pada Program Studi Pendidikan Biologi di Universitas Muhammadiyah Palembang. Edunesia: Jurnal Ilmiah Pendidikan, 2(1), 171-177. https://doi.org/10.51276/edu.v2i1.114.

Lestariningsih, N., \& Suardiman, S. P. (2017). Pengembangan Bahan Ajar Tematik-Integratif Berbasis Kearifan Lokal Untuk Meningkatkan Karakter Peduli Dan Tanggung Jawab. Jurnal Pendidikan Karakter, 7(1). https://doi.org/10.21831/jpk.v7i1.15503.

Linda, R., Herdini, Sulistya, I., \& Putra, T. P. (2018). Interactive E-Module Development through Chemistry Magazine on Kvisoft Flipbook Maker Application for Chemistry Learning in Second Semester at Second Grade Senior High School. Journal of Science Learning, 2(1), 21-25. https://doi.org/10.17509/jsl.v2i1.12933.

Liu, X., Kong, J., Jiang, M., \& Li, S. (2021). Interactive information module for person re-identification. Journal of Visual Communication and Image Representation, 75. https://doi.org/10.1016/j.jvcir.2021.103033.

Majid, M. S. Z. B. A., Ali, M. M. B. A., Rahim, A. A. B. A., \& Khamis, N. Y. B. (2012). The Development of Technical English Multimedia Interactive Module to Enhance Student Centered Learning (SCL). Procedia - Social and Behavioral Sciences, 67, 345-348. https://doi.org/10.1016/j.sbspro.2012.11.337.

Martha, nia ulfa, \& Andini, novita pri. (2019). Pengembangan Bahan Ajar Mata Pelajaran Bahasa Indonesia Berbasis Cerita Rakyat Kabupaten Banjarnegara. Jurnal Inovasi Pembelajaran, 5(2). https://doi.org/10.22219/jinop.v5i2.9992.

Mayarnimar, \& Taufina. (2017). Validity Analysis of the VARK (Visual, Auditory, Read-Write, and Kinesthetic) Model - Based Basic Reading and Writing Instructional Materials for the 1st Grade Students of Elementary School. Atlantis Press, 118, 870-874. https://doi.org/10.2991/icset17.2017.141.

McNamara, J., Sweetman, S., Connors, P., Lofgren, I., \& Greene, G. (2020). Using Interactive Nutrition Modules to Increase Critical Thinking Skills in College Courses. Journal of Nutrition Education and Behavior, 5(4). https://doi.org/10.1016/j.jneb.2019.06.007.

Mishra, L., Gupta, T., \& Shree, A. (2020). Online teaching-learning in higher education during lockdown 
period of COVID-19 pandemic. International Journal of Educational Research Open, 1, 100012. https://doi.org/10.1016/j.ijedro.2020.100012.

Neppala, P., Sherer, M. V., Larson, G., Bryant, A. K., Panjwani, N., Murphy, J. D., \& Gillespie, E. F. (2018). An interactive contouring module improves engagement and interest in radiation oncology among preclinical medical students: Results of a randomized trial. Practical Radiation Oncology, 8(4). https://doi.org/10.1016/j.prro.2018.01.001.

Nugroho, A., Ilmiani, D., \& Rekha, A. (2021). EFL Teachers' Challenges and Insights of Online Teaching amidst Global Pandemic. Metathesis: Journal of English Language, Literature, and Teaching, 4(3), 277. https://doi.org/10.31002/metathesis.v4i3.3195.

Nurafni, A., Pujiastuti, H., \& Mutaqin, A. (2020). Pengembangan Bahan Ajar Trigonometri Berbasis Kearifan Lokal. Journal of Medives : Journal of Mathematics Education IKIP Veteran Semarang, 4(1), 71. https://doi.org/10.31331/medivesveteran.v4i1.978.

Nurjannah. (2018). Pengaruh Media Gambar Terhadap Motivasi Belajar Pelajaran Bahasa Indonesia Kelas Iii Sdn Pasi Pinang. Bina Gogik, https://ejournal.stkipbbm.ac.id/index.php/pgsd/article/view/17.

Owon, R. A. S. (2017). Pengembangan Bahan Ajar Menulis Berbagai Jenis Teks Bertema Kearifan Lokal Sikka Bagi Siswa SMP. Jurnal Inovasi Pembelajaran, 3(1), 528-541. https://doi.org/10.22219/jinop.v3i1.4318.

Oyedotun, T. D. (2020). Sudden change of pedagogy in education driven by COVID-19: Perspectives and evaluation from a developing country. Research in Globalization, 2(June), 100029. https://doi.org/10.1016/j.resglo.2020.100029.

Pasaribu, A., \& Saparini. (2017). Pengembangan Bahan Ajar Berbasis Kontekstual untuk Meremidiasi Miskonsepsi pada Materi Gaya dan Hukum Newton. Jurnal Inovasi Dan Pembelajaran Fisika, 4(2), 36-47. https://doi.org/10.36706/jipf.v4i1.4264.

Patricia, A. (2020). College Students' Use and Acceptance of Emergency Online Learning Due to COVID-19. International Journal of Educational Research Open, 100011. https://doi.org/10.1016/j.ijedro.2020.100011.

Pratiwi, P. H., Nur, H., \& Martiana, A. (2017). Pengembangan Modul Mata Kuliah Penilaian Pembelajaran Sosiologi Berorientasi Hots. Jurnal Cakrawala Pendidikan, 36(2), 201-209. https://doi.org/https://doi.org/10.21831/cp.v36i2.13123.

Prihandoko, Y., Slamet, S. Y., \& Winarno. (2017). Pendekatan Cognitive Moral Sebagai Kerangka Pengembangan Bahan Ajar Ppkn Di Sekolah Dasar. Jurnal Kependidikan, 1(2), 200-2013.

Putri, I. H. N., Sholihah, U., Handayani, E. M., \& Sumarmi, S. (2018). Pengembangan Suplemen Bahan Ajar Digital Pada Mata Pelajaran Geografi Dengan Topik Bahasan Sumber Daya Laut Berbasis Kearifan $\begin{array}{lllll}\text { Lokal. Jurnal } & \text { Pendidikan }\end{array}$ https: //doi.org/10.17977/um017v23i22018p078.

Rasmawan. (2018). Development of Chemistry Module for Junior High School Based on Inquiry Accompanied by Performance-Based Assessment. Jurnal Pendidikan Indonesia, 7(2), 111-119. https://doi.org/10.23887/jpi-undiksha.v7i2.10617.

Riwu, I. U., Laksana, D. N. L., \& Dhiu, K. D. (2018). Pengembangan Bahan Ajar Elektronik Bermuatan Multimedia Pada Tema Peduli Terhadap Makhluk Hidup Untuk Siswa Sekolah Dasar Kelas Iv Di Kabupaten Ngada. Journal of Education Technology, 2(2), 56. https://doi.org/10.23887/jet.v2i2.16182.

Rusli, R., Rahman, A., \& Abdullah, H. (2020). Student perception data on online learning using heutagogy approach in the Faculty of Mathematics and Natural Sciences of Universitas Negeri Makassar, Indonesia. Data in Brief, 29, 105152. https://doi.org/10.1016/j.dib.2020.105152.

Sahu, P. (2020). Closure of Universities Due to Coronavirus Disease 2019 (COVID-19): Impact on Education and Mental Health of Students and Academic Staff. Cureus, 2019(4), 4-9. https://doi.org/10.7759/cureus.7541.

Saidah, K., \& Damariswara, R. (2019). Pengembangan Bahan Ajar Materi Dongeng Berbasis Kearifan Lokal Jawa Timur Bagi Siswa Kelas III SD. Premiere Educandum: Jurnal Pendidikan Dasar Dan Pembelajaran, 9(1), 73. https://doi.org/10.25273/pe.v9i1.4320.

Silalahi, M. V. (2020). Development of E-Modules Based on Exe-Learning on Topics of Reaction Rate Against Student Learning Outcomes Mechanical Engineering. International Journal of Education and Curriculum Application, 3(2), 114-120. https://doi.org/10.31764/ijeca.v3i2.2672.

Sriyanti, I., Almafie, M. R., Marlina, L., \& Jauhari, J. (2021). The effect of Using Flipbook-Based E-modules on Student Learning Outcomes. Kasuari: Physics Education Journal (KPEJ), 3(2), 69-75. https: //doi.org/10.37891/kpej.v3i2.156.

Sugiyono. (2018). Metode Penelitian Kuantitatif. Alfabeta. 
Suzuki, S. N., Akimoto, Y., Suzuki, K., Okada, A., Hirata, K., Kato, T., Yajima, K., Kanematsu, H., Fukumoto, T., \& Yoshikawa, F. (2020). Development of A-txt system compatible introductory teaching materials for Electric Power Engineering using gaming simulation. Procedia Computer Science, 176, 15571566. https://doi.org/10.1016/j.procs.2020.09.167.

Syafii. (2017). Pengembangan Bahan Ajar Ornamen Berbasis Candi di Jawa Tengah: Studi Identifikasi Candi Gedongsanga. Imajinasi Jurnal Seni, 11(2), 117-124. https://doi.org/https://doi.org/10.15294/imajinasi.v11i2.12813.

Tchen, P., Leung, L., Simpson, F., Kim-Sing, A., \& Pearson, M. L. (2018). Bridging the gap: An evaluation of self-paced online transition modules for advanced pharmacy practice experience students. Currents in Pharmacy Teaching and Learning, 10(10). https://doi.org/10.1016/j.cptl.2018.07.006.

Tinja, Y., Towaf, S. M., \& Hariyono. (2017). Pengembangan Bahan Ajar Tematik Berbasis Kearifan Lokal Sebagai Upaya Melestarikan Nilai Budaya Pada Siswa Sekolah Dasar. Jurnal Pendidikan: Teori, Penelitian, Dan Pengembangan, 2(9), 1257-1261. https://doi.org/10.17977/jptpp.v2i9.9990.

Triwahyuningtyas, D., Ningtyas, A. S., \& Rahayu, S. (2020). The problem-based learning e-module of planes using Kvisoft Flipbook Maker for elementary school students. Jurnal Prima Edukasia, 8(2), 199208. https://doi.org/10.21831/jpe.v8i2.34446.

Tsai, H. C., Jou, M., Wang, J. Y., \& Huang, C. C. (2017). An empirical study on the incorporation of APP and progressive reasoning teaching materials for improving technical creativity amongst students in the subject of automatic control. Computers in Human Behavior, 75, 997-1007. https: //doi.org/10.1016/j.chb.2016.10.031.

Velan, G. M., Goergen, S. K., Grimm, J., \& Shulruf, B. (2015). Impact of Interactive e-Learning Modules on Appropriateness of Imaging Referrals: A Multicenter, Randomized, Crossover Study. Journal of the American College of Radiology, 12(11). https://doi.org/10.1016/j.jacr.2015.06.026.

Wei, X., Saab, N., \& Admiraal, W. (2021). Assessment of cognitive, behavioral, and affective learning outcomes in massive open online courses: A systematic literature review. Computers \& Education, 163. https://doi.org/10.1016/j.compedu.2020.104097.

Weriyanti, W., Firman, F., Taufina, T., Taufina, T., \& Zikri, A. (2020). Pengembangan Bahan Ajar Tematik Terpadu dengan Strategi Question Student Have di Sekolah Dasar. Jurnal Basicedu, 4(2), 476-483. https: //doi.org/10.31004/basicedu.v4i2.374.

Wibowo, R., Widiati, U., \& Santoso, A. (2017). Bahan Ajar Tematik Materi Puisi Kelas V SD dengan Pemanfaatan Peta Pikiran dan Lingkungan sekitar. Jurnal Pendidikan: Teori, Penelitian, Dan Pengembangan, 2(6), 743-750.

Yati, W., \& Amini, R. (2020). Pengembangan Bahan Ajar Dengan Pendekatan Cooperative Learning Tipe Turnamen Pada Siswa Kelas IV SD. Jurnal Basicedu, 4(1), 158-167. https: //doi.org/10.31004/basicedu.v4i1.335.

Yilmaz, E., \& Korur, F. (2021). The Effects of an Online Teaching Material Integrated Methods on Students' Science Achievement, Attitude and Retention. International Journal of Technology in Education, 4(1). https://doi.org/10.46328/ijte.79.

Yulando, S., Sutopo, S., \& Franklin Chi, T. (2019). Electronic Module Design and Development: An Interactive Learning. American Journal of Educational Research, 7(10), 694-698. https: //doi.org/10.12691/education-7-10-4.

Yunita, N. K. D., \& Tristiantari, N. K. D. (2018). Pengaruh Model Pembelajaran Kooperatif Tipe TGT Berbasis Kearifan Lokal Tri Hita Karana Terhadap Hasil Belajar. Jurnal Penelitian Pendidikan Guru Sekolah Dasar, 6(6), 96-107. http://dx.doi.org/10.23887/jpmu.v1i2.20778. 